\title{
ECONOMICS
}

\section{WESTERN AUSTRALIA'S DOMESTIC GAS RESERVATION POLICY THE ELEMENTAL ECONOMICS}

by

Kelly Neill

Business School

University of Western Australia 


\title{
WESTERN AUSTRALIA'S DOMESTIC GAS RESERVATION POLICY THE ELEMENTAL ECONOMICS
}

\author{
Kelly Neill ${ }^{1}$ \\ Business School, University of Western Australia
}

March 2015

DISCUSSION PAPER 15.08

\begin{abstract}
Western Australia introduced a domestic gas reservation policy in 2006, which requires new gas developments to supply the equivalent of 15 per cent of their gas exports to the Western Australian domestic gas market. The aim of the policy is to maintain domestic gas prices below export parity. It has been regarded as having the same effects as a tax on production and a subsidy on domestic consumption, with the attendant economic costs. This paper improves on this interpretation by recognising that the policy imposes a proportional relationship between export and domestic supply. While the model developed is consistent with the tax-subsidy interpretation, it enables the quantification of the links between the implicit tax and subsidy rates, the proportion of gas reserved and the domestic market price. The results indicate that a binding reservation policy always causes a deadweight loss. While activity in gas-using industries expands, this does not yield an overall benefit to the economy in the long run. Gas production is reduced and income is foregone because some gas is diverted to lower value uses. The work offers early results from a larger project to model the Australian natural gas industry within a general equilibrium setting.
\end{abstract}

Key Words: Energy policy, domestic gas reservation, natural gas pricing, trade restrictions

\section{Corresponding author:}

Kelly Neill

UWA Business School

35 Stirling Highway Crawley WA 6009 Australia

kelly.neill@research.uwa.edu.au

\footnotetext{
${ }^{1}$ The author would like to acknowledge Rodney Tyers, Peter Hartley and participants at the University of Western Australia economics seminar for valuable comments and assistance. This research was supported in part by funding from Woodside Petroleum.
} 


\section{Introduction}

Under Western Australia’s domestic gas reservation policy the State Government requires new gas developments to supply the equivalent of 15 per cent of their Liquefied Natural Gas (LNG) exports to the Western Australian domestic gas market. Although the policy is not formalised in legislation, it is enforced by the Government via their right to deny access to land (or potentially state waters) for LNG plants and infrastructure. The policy might be seen as a more formal version of the domestic supply provisions contained in previous 'State Agreements’ between gas suppliers and the State Government.

This paper investigates the elemental economics of the policy and its likely impacts, using a generic approach that has relevance wherever such policies are under consideration. For example, there have been recent proposals to introduce similar policies in the eastern states.

Domestic gas reservation policies are intended to increase the supply of gas to domestic markets ensuring that domestic prices are retained below export parity. Thus, such policies can be thought of as having the same effect as two simultaneous distortions in the gas market: a tax on domestic producers, since they are receiving a lower price than otherwise; and a subsidy for domestic consumers, since they are paying a lower price than otherwise. It follows that the distortionary effects of the policy are detrimental to the economy in the same way that a tax and subsidy are each individually detrimental. This is the prevailing interpretation of such reservation policies.

This paper offers an elemental model which explicitly recognises that the gas reservation policy imposes a proportional relationship between export and domestic supply. The associated deadweight loss is thus clarified. It extends and improves upon the treatment of such policies by other authors, including the Bureau of Resources and Energy Economics [BREE] (2014b), Deloitte Access Economics [DAE] (2013) and the Economic Regulation Authority [ERA] (2014), whose focus on the policy as an implicit tax and subsidy misses the role of proportionality between exports and domestic supply.

Section 2 of this paper discusses the context of the reservation policy and the projects to which it has been applied in Western Australia. The related literature is surveyed in Section 3 and the model is presented in Section 4, both in graphical and mathematical form. Section 5 then discusses a number of additional considerations, including: whether the 15 per cent reservation policy is likely to be binding; additional costs from imposing reservation on 
individual projects; the implications of foreign ownership; the effect of government 'flexibility' in the proportion reserved by each project; and whether the benefits for downstream, gas-using industries outweighs the losses in the upstream gas sector. A summary and conclusions are offered in Section 6.

\section{Context of the reservation policy}

A key aim of Western Australia's reservation policy is to secure higher levels of domestic gas supply and thereby maintain lower domestic gas prices than may prevail without the policy intervention. Some analysts have suggested that the policy "appears to have been the Western Australian Government's response to ... a sharp spike in gas prices and tight supply of domestic gas” (ERA, 2014).

Indeed, historically domestic gas prices in Western Australia have been stable and relatively low, owing mainly to the long-term contracts held by major domestic consumers with the North West Shelf (NWS) project, which were entered into during the 1980s. As shown in Figure A, domestic gas prices have been rising in recent years, to \$4.70 per GJ in 2012-13 from $\$ 2.30$ per GJ in 2004-05. This has been the result of a combination of factors, including the expiry of the original long-term contracts and the increasing level of international competition for Western Australian gas. (BREE, 2013)

\section{[Insert Figure A]}

The historically low prices seem to have limited investment in new domestic gas processing capacity. However, more recently supply has been responding to the higher prices, with the Devil Creek and Macedon ${ }^{2}$ plants constructed to service the domestic market. The Devil Creek gas plant, which commenced operations in 2011 was "the first new plant built in Western Australia in almost 20 years” (Apache, 2013).

Western Australia has exported LNG from the North West Shelf (NWS) project since 1989. The Pluto LNG project then came online in 2012. Four other projects drawing on gas off the northern Western Australian coast are currently under construction (APPEA, 2014). However, only two of these new projects will process and liquefy the gas using onshore plants in Western Australia - the Wheatstone and Gorgon projects.

\footnotetext{
2 The Macedon gas plant commenced operations in September 2013 (BHP Billiton 2013).
} 
The reservation policy has been applied to some of these onshore LNG developments, while State Agreements govern domestic supply commitments for the other projects. The Pluto and Wheatstone projects will each supply the equivalent of 15 per cent of their LNG exports to the domestic market under the reservation policy, although there is a delay between the commencement of LNG exports and domestic supply (Independent Market Operator [IMO], 2013). The NWS Joint Venture has also signed a State Agreement to supply domestic gas equivalent to 15 per cent of the LNG from two new fields, consistent with the reservation policy (WA Government, 2014). A domestic supply requirement was also imposed on the Gorgon Joint Venture, which agreed to supply a total of 2,000 PJ to the domestic market under a State Agreement (IMO, 2013).

Two gas export projects currently under construction have been able to avoid the reservation policy by locating their production facilities outside Western Australia. The Prelude project will utilise Floating LNG technology, so that the gas is liquefied at sea rather than onshore. The Ichthys project will transport gas via "one of the longest subsea pipelines ever built" to Darwin for liquefaction (Inpex, 2015).

\section{Literature Review: Economic impacts of gas reservation}

A number of studies have examined the economic impact of domestic gas reservation policies, both in Western Australia and in the eastern states. As discussed in this section, most of these studies have opposed domestic gas reservation, recognising that the costs incurred in the upstream gas sector outweigh any benefits to domestic gas consumers. However, there are some studies that support gas reservation based on the benefits to gasusing industries, although these studies rely on some naïve assumptions. ACIL Allen (2014) contains a good analysis of the flaws in these studies.

A number of recent studies recognise both the costs to gas producers from gas reservation and the benefits to gas consumers. They generally characterise the policy as an "implicit tax on gas producers that, rather than going to the government, provides domestic gas users with a price subsidy.” (BREE 2014b, p112). Examples include studies by ACIL Allen (2014); BREE (2014a, 2014b); Deloitte Access Economics (2013); the Economic Regulatory Authority (2014); and Wood et al. of the Grattan Institute (2013).

As noted above, the domestic gas reservation policy acts as an implicit tax on Australian gas production. When additional gas is diverted to the domestic market, producers must accept 
lower domestic prices than they otherwise would. This reduces incentives for investment in gas production and exploration. As noted by BREE "there is a relatively lower level of investment in new supply compared to not having the reservation policy and, therefore total gas production is lower than otherwise.” (BREE 2014b p115) Less interest in discovering and developing potentially large new sources of natural gas in the state, would unambiguously involve economic losses for Western Australia, or any other jurisdiction with a reservation policy.

In addition to having the effect of a production tax, a domestic gas reservation policy also acts as an implicit subsidy for domestic consumers. The diversion of gas from the export market to the domestic market lowers the price that domestic consumers pay for gas. Just as a normal subsidy encourages resources, such as labour and capital, to move into industries where their productivity is lower than it could otherwise be, the domestic gas reservation policy diverts resources into less productive uses. An artificially low gas price reduces production costs in gas-using industries, and so they are able to expand production. Gasusing industries hire additional labour and invest in additional capital. However, these resources could otherwise have been employed in industries where no subsidy is necessary, that is, where labour and capital have a higher value. Simply put, an artificially-low gas price "perpetuates the existence of industries that may not have a comparative advantage in WA at the expense of investment in other industries” (ERA 2014, p293). The flow-on effects to gasusing sectors are discussed further in Section 5.5.

Likewise, some studies also point out that artificially low domestic gas prices can increase reliance on low-cost gas, leading to additional costs such as a lack of technical innovation and dynamic efficiency. "For example, the policy artificially depresses domestic prices, which discourages domestic gas users to invest in technologies to lower or substitute their gas consumption.” (ERA 2014, p292)

In summary, the two separate components of a domestic gas reservation policy are detrimental to overall Australian living standards. First, the implicit tax on producers lowers the incentive to invest in gas exploration and production, lowering overall activity in the domestic economy. Second, the implicit subsidy results in an opportunity cost by lowering the value of Australia's gas. It shifts labour and capital into gas-intensive industries from other sectors of the economy, but this should be viewed as a diversion of resources to lowervalue uses rather than a generation of new activity. 
The above-mentioned studies support this interpretation and find that domestic gas reservation is likely to be detrimental to Australian living standards. For example, BREE finds that domestic gas reservation "is likely to see a reduction in economic welfare if Australia foregoes export earnings (and tax revenues) in favour of (presumably lower value) domestic production, and lower future exploration and gas development activity.” (BREE 2014a, p107) The Economic Regulation Authority of Western Australia goes further and recommends that the domestic gas reservation policy be rescinded as soon as possible (ERA 2014, p383).

Deloitte Access Economics (2013) models the effect of introducing a reservation policy in the eastern states and finds that the economic costs outweigh any advantages for domestic gas users, and Australians are worse off as a result. The study achieves this by using a combination of a tax and subsidy regime to represent the effect of the reservation policy.

\section{Model of the domestic gas reservation policy}

This section presents a partial equilibrium model of the gas sector and applies a domestic gas reservation policy to it, showing the effect on domestic supply and prices. Most importantly, it also shows the net loss from the reservation policy, the deadweight loss, where gains to gas consumers only partially offset losses to gas producers.

In a key innovation, the model contains an explicit representation of the reservation policy, treating it as imposing a proportional relationship between domestic and export supply. This improves on the conventional modelling of the policy as a tax-subsidy combination, as has been done by the studies mentioned in the previous section. However, the model is consistent with this idea, and shows how the implicit tax and subsidy rates are related to the proportion of supply that is reserved for the domestic market.

\subsection{The undistorted market}

The starting point is the standard model of a trade-exposed market, for the case of an exporter. As shown in Figure B, demand and supply curves are linear for simplicity.

\section{[Insert Figure B]}

Export demand for gas is assumed to be perfectly elastic, so the export price for gas, $P^{W}$, is exogenous. In the context of this model, the relevant export price is the LNG netback price the price paid for LNG by international consumers less the additional costs associated with 
gas exports, such as the cost of liquefaction and shipping. This analysis excludes any domestic transport costs.

On the other hand, the domestic price for gas, $P^{D}$, will be lower the greater the quantity supplied to the domestic market, $D$. This relationship is represented with a downwardsloping demand curve:

$$
P^{D}=a-b D
$$

The increasing marginal cost of domestic gas production is captured in the upward sloping supply curve: to increase total supply, $S$, producers must move into gas fields that are increasingly expensive to develop and thus require a higher producer price, $P^{P}$, to do so. The supply curve is:

$$
P^{P}=c-d S
$$

which implies the following total cost function:

$$
T C=S+\frac{d}{2} S^{2}
$$

To discuss the reservation policy, the model explicitly includes the producer's choice of what proportion, $\alpha$, of total production, $S$, to supply to the domestic market. The producer's problem is to choose $\alpha$ and $S$ to maximise profits, as follows.

$$
\max _{\alpha, S} \pi=P^{D} \alpha S+P^{W}(1-\alpha) S-c S-\frac{d}{2} S^{2}
$$

Solving the first order conditions gives the familiar result that the representative producer will choose $\alpha$ so that export parity pricing is achieved, where $P^{D}=P^{W}$. This, together with the first order conditions, gives an expression for the profit-maximising total supply and domestic market share:

$$
\begin{aligned}
& S^{*}=\frac{1}{d}\left[P^{W}-c\right] \\
& \alpha^{*}=\frac{d}{b} \frac{\left(a-P^{W}\right)}{\left(P^{W}-c\right)}
\end{aligned}
$$

These are consistent with the familiar outcomes for $D$ and $S$ shown in Figure B.

\subsection{Effect of a domestic gas reservation policy}

A binding reservation policy sets a minimum proportion of production to be supplied on the domestic market, $\bar{\alpha}$, where $\bar{\alpha}>\alpha^{*}$. That is, for any total supply, $S$, the amount sold on the domestic market, $D$, must be at least $\bar{\alpha} S$. This implies a domestic supply curve as follows. 


$$
P^{D}=c+\frac{d}{\bar{\alpha}} D
$$

The domestic supply curve is shown in Figure C.

\section{[Insert Figure C]}

Since the reservation policy imposes a proportional relationship between total production and domestic supply, the representative producer no longer has the freedom to choose domestic supply to equate the export and domestic prices. Instead, the domestic price can fall below the export parity price.

In the presence of the reservation policy, the representative producer can only choose total supply to maximise their profits, as follows.

$$
\max _{S} \pi=P^{D} \bar{\alpha} S+P^{W}(1-\bar{\alpha}) S-c S-\frac{d}{2} S^{2}
$$

Solving this problem gives the profit-maximising rule for total supply under the domestic gas reservation policy:

$$
\bar{\alpha} P^{D}+(1-\bar{\alpha}) P^{W}=c+d \bar{S}
$$

That is, the representative producer chooses total supply so that the marginal cost of production is equal to the weighted average of the world and domestic prices. Under a binding reservation policy, this weighted average price is actually the marginal price that the producer receives for additional gas, since for any additional production the share $\bar{\alpha}$ must always be sold on the domestic market.

These conditions can be used to show that, for any $\bar{\alpha}>\alpha^{*}$, the domestic price will be lower than the international price (see the Appendix for more details). This can be understood intuitively from Figure D, which represents the market outcome in the presence of the domestic gas reservation policy, showing domestic supply, $\bar{D}$, and total supply, $\bar{S}$.

\section{[Insert Figure D]}

Figure D also shows that a domestic gas reservation policy reduces both total production and exports, but increases domestic supply compared to the undistorted equilibrium.

This model of the domestic gas reservation policy is consistent with its interpretation as a tax on domestic production combined with a subsidy on domestic consumption. The production tax rate, $t$, is the percent difference between the world price and the producer price (which is 
the weighted average of the domestic and export prices). The consumption subsidy rate, $s$, is the percent difference between the world and domestic consumer prices. Figure E shows the implicit tax and subsidy rates diagrammatically.

\section{[Insert Figure E]}

Using this model, it can be shown that the tax and subsidy rates are related as follows:

$$
t=\bar{\alpha} s
$$

The deadweight loss resulting from the domestic gas reservation policy can also be calculated, as follows:

$$
D W L=\frac{t}{2} S^{*}\left(\frac{\alpha^{*}}{\bar{\alpha}}-1\right)
$$

This is always negative whenever the reservation policy is binding, $\bar{\alpha}>\alpha^{*}$, so a reservation policy will always produce an economic loss. The deadweight loss is the shaded area in Figure E. The triangle on the right-hand-side is the loss associated with the production tax component, which causes a reduction in overall gas production. The triangle on the lefthand-side is the loss associated with the subsidy component, the opportunity cost from selling the gas at less than the export price.

More details of the derivation of equations (10) and (11) are included in the Appendix, including equations for the implied tax and subsidy rates.

\section{Further considerations}

The model developed in this paper is an elemental representation of a domestic gas industry subject to a reservation policy. It serves as an instructive starting point for a quantitative analysis of the economic loss associated with such a policy. This section considers some further issues and their implications for policy analysis. These issues are 1) whether a 15 per cent reservation policy is likely to be a binding constraint that alters the decisions of LNG producers, 2) the additional costs imposed by applying the reservation policy at the project level rather than at the industry level, 3) the implications of foreign ownership of gas producers and gas consumers, 4) whether flexibility in the share reserved is likely to ameliorate the economic costs of the policy and 5) why the benefits to gas consumers do not offset the costs to gas producers. In considering these issues, this section also points to areas for future research. 


\subsection{Does a 15 per cent reservation policy bind?}

Based on figures reported by the Independent Market Operator (IMO 2014), in 2012-13 domestic consumption of gas in Western Australia was 9.1 billion cubic metres (bcm) ${ }^{3}$ while, according to BREE (2014c), production in the state was $38.9 \mathrm{bcm}$. That is, domestic consumption was around 23 per cent of total production, as shown in Figure F. On the other hand, if the reservation policy were binding for all gas projects in Western Australia, then they would be obliged to supply around 13 per cent of total production to the domestic market. $^{4}$

On first consideration, this may suggest that the domestic gas reservation policy is unlikely to be binding, since producers are already suppling greater than the minimum proportion to the domestic market. However, this simple interpretation does not suffice for two reasons. First, LNG exports are expected to grow significantly over coming years, which will tend to increase the export share and reduce the domestic share. Second, the economic impact of the policy depends on how it affects decisions made by the marginal project, rather than the overall level of domestic supply. These issues are discussed in turn.

\section{[Insert Figure F]}

In coming years, the proportion of gas that is consumed locally in Western Australia is set to fall from its current level of 23 per cent. As more export projects come on-line, production levels will increase. At the same time, the IMO forecasts that growth in domestic demand is likely to be very slow, at an average of between 0.3 and 1.3 per cent each year to 2024 . Based on these forecasts, by 2018-19 domestic gas consumption could fall to around 13 per cent of total Western Australian production (and 14 per cent if the IMOs more optimistic forecasts for demand eventuate). If exports continue to grow, then domestic consumption could fall to an even lower share following this period. This industry-wide indicator suggests that the reservation policy is likely to be binding. However, since the policy is applied on a project-by-project basis, it is important to also consider its effect on the decisions of each project.

\section{[Insert Figure G]}

\footnotetext{
${ }^{3}$ This domestic consumption figure excludes gas used in LNG processing.

${ }^{4}$ This figure is less than the headline policy rate of 15 per cent for two reasons. Firstly, the reservation policy requires that the equivalent of 15 per cent of $L N G$ production be supplied to the domestic market, which is less than 15 per cent of total production. Secondly, some gas is expended during liquefaction. Following IMO (2014, p59), we assume that the equivalent of 8 per cent of total LNG feedstock is used during this process.
} 
Figure $\mathrm{G}$ confirms that domestic production capacity greatly exceeds domestic demand. According to the IMO, by the third quarter in 2014, unused capacity had grown to "one third of total domestic gas production capacity” (IMO, 2014 p109). With the addition of new domestic production facilities, including the Gorgon and Wheatstone facilities under the reservation policy, “domestic production capacity is projected to be almost double the forecast level of domestic gas demand by the end of 2024” (IMO, 2014 p6). In this environment, with low demand growth and over-capacity, it is unlikely that producers would choose to construct additional domestic production facilities and infrastructure to serve the domestic market in the absence of the reservation policy. Therefore, a domestic gas reservation policy is likely to be binding for new LNG projects in Western Australia in the sense that these projects would not otherwise supply the domestic market.

\subsection{What are the additional costs of imposing reservation at the project level?}

The application of the reservation policy to each project, rather than the industry as a whole, implies additional costs for the gas sector. Clearly, if all gas projects are required to construct additional facilities to serve the domestic gas market, when the costs of such facilities are very high for some, this could add substantially to the cost of producing domestic gas. In the absence of the policy, only developers who find it less costly to serve the domestic market compared to their competitors would do so. Instead, if all developers are required to supply the domestic market, the likely result will be a domestic supply chain with investment that is inefficiently sized or in the wrong location ${ }^{5}$. However, allowing exporting firms to contract with third parties to supply their domestic gas obligation could lessen some of these inefficiencies.

\subsection{Does foreign ownership affect the conclusion?}

Foreign ownership of energy companies is an issue raised in a number of studies, including ACIL Allen (2014). The reservation policy can be thought of as a transfer of income from gas-producing firms to gas-consuming firms. Therefore, if gas-producing firms have higher foreign ownership shares than gas-consuming firms, then the reservation policy may act to transfer some income from foreigners to Australians. However, data on ownership of firms

\footnotetext{
${ }^{5}$ This additional cost is not explicitly included in the model presented in Section 3 of this paper, since it models the reservation policy as if it were applied at the industry level rather than the project level. However, work is underway to construct a quantitative model that does take these additional costs into account by modelling gas supply on a project-by-project basis.
} 
participating in Western Australia's gas market is not available, so it is difficult to judge the net benefits of such income transfers.

Gas producers in Western Australia include a number of international and domestic energy firms. Shareholders in these companies may be domestic or foreign financial institutions, superannuation companies or households.

The share of gas consumed by each industry in Western Australia is shown on Figure H. Interestingly, households make up only 2 per cent of total domestic gas demand. Large gasusers in the manufacturing industry include alumina and fertiliser manufacturers. Mining companies also make up a significant proportion of Western Australia’s domestic gas demand. These gas-using companies can be owned by the same array of domestic or foreign shareholders as gas-producing companies. One exception is the electricity sector, where a significant proportion of generation capacity is owned by the State Government. However, the costs and benefits of government ownership of utilities is a separate issue and will not be discussed here.

\section{[Insert Figure H]}

An additional consideration is that the reservation policy is likely to reduce tax collections since gas-producing companies tend to pay higher taxes than gas-consuming companies. In this way, the reservation policy would reduce domestic tax revenue (and therefore income) from resources.

Therefore, it is not necessarily the case that the reservation policy will transfer income from foreigners to domestic households and governments. However, further research on taxation and domestic ownership is required before conclusions in this area can be drawn.

\subsection{Does ‘flexibility' in reservation requirements help?}

The 2011 Western Australian Parliamentary Inquiry into domestic gas prices noted that, “The Reservation Policy allows for ‘case-by-case flexibility’, allowing potential producers to negotiate with government as to the amount to be reserved and the manner in which it is to be supplied.” (Parliament of Western Australia, Economics and Industry Standing Committee 2011, p79)

The Government may believe that flexibility in the share of gas sold on the domestic market could make the policy less harmful. For example, the domestic gas reservation requirement could be relaxed for projects that might be uneconomic if it were enforced. This line of 
thought is also raised in a recent report by the Oxford Institute for Energy Studies (Ledesma et al., 2014). However, the possibility of 15 per cent domestic reservation will itself tend to discourage investment in exploration for new gas resources, so it is unlikely that this flexibility will substantially reduce the policy’s detrimental effects.

In addition, this 'flexibility’ also creates uncertainty for gas producers about the quantity of gas that they will be required to sell on the domestic market. This uncertainty, in itself, would tend to discourage investment. For example, the uncertainty created by a flexible reservation policy ranging from 11 to 15 per cent with a mean of 13 per cent would discourage investment to a greater extent than a commitment to a 13 per cent rate for all projects. ${ }^{6}$

\subsection{Do benefits in gas-using industries offset the loss in the gas industry?}

The main loss from a distortion, such as the reservation policy, is the deadweight loss arising within the distorted market itself. The deadweight loss from the reservation policy was discussed in Sections 2 and 3. The gain to domestic gas consumers from additional gas supply was shown to be more than offset by losses to gas producers.

The benefit of additional domestic gas supply to downstream gas-users is embodied in the demand curve for the gas sector. Specifically, the demand curve shows the amount that industries, such as the electricity, alumina or fertiliser sectors, are willing to pay for a marginal additional unit of gas. This amount is equivalent to the additional value that the additional gas inputs would contribute to the outputs of these downstream industries. Domestic industries are only willing to pay less than the export price for the additional gas supplied under the reservation policy, so the value of this gas to the Australian economy is pushed below what it would have been if exported. On other words, the reservation policy diverts gas to lower-value uses, and results in an opportunity cost for the Australian economy.

Additional gas supplied to the domestic market would indeed lead to an expansion in gasusing sectors, raising employment and investment in these industries. However, the expansion of gas-using industries does not necessarily imply an increase in overall employment or capital income for Australians in the long run. Expanded employment in gasusing sectors leaves less labour available for other industries and would not be expected to

\footnotetext{
${ }^{6}$ There is a growing literature on the negative impact of policy uncertainty on investment. For example, Pastor and Veronesi (2012) develop a model explaining why uncertainty about the impact of a policy on profitability is likely to push stock prices down. Gulen and Ion (2013) show empirically that higher policy-related uncertainty reduces industry investment.
} 
increase overall long-run employment levels. Additional capital must be paid for, and foreign investors are the most likely source of this additional funding, meaning that the capital income of Australians is unlikely to change through an expansion in gas-using industries. Therefore, the gas reservation policy is unlikely to increase overall employment and capital incomes, but instead shifts activity into less efficient industries.

In general, a partial equilibrium approach, such as the one presented in this paper, can give sufficient information to draw policy conclusions because it captures both the main losses and benefits from the reservation policy. While a general equilibrium analysis would extend the detail of the results to show the extent to which gas-using industries expand and other industries contract, it is unlikely to change the overall conclusion regarding the economic cost of the policy.

However, one caveat for using a partial equilibrium analysis of the gas sector is the potential influence of distortions in other sectors of the economy. For example, if there were significant tax or other policy distortions in gas-using industries, then it is possible that the domestic gas reservation policy may partially or wholly offset these distortions. An appropriate general equilibrium analysis could pick up any of these effects. It is important to note here that the domestic gas reservation policy is not offsetting any perceived market failure or other distortion in the gas sector. As BREE notes "It is generally accepted that the higher domestic gas prices from linking to an export market are due to market dynamics and not a market failure.” (BREE 2014b, p116)

Gohin and Moschini (2006) assessed the difference between partial and general equilibrium models when analysing distortions in agricultural sectors of developed countries. In line with the above, they found that partial equilibrium models yielded 'comparable implications' to general equilibrium models, assuming that no other major distortions exist in the rest of the economy. However, this was not the case when significant distortions existed in other markets, such as labour-market rigidity.

General equilibrium modelling of a gas reservation policy in the eastern states by Deloitte Access Economics (2013) reported results that are qualitatively similar to the partial equilibrium model developed in this paper. As mentioned in Section 3, the study found that any benefits of a reservation policy to gas-using sectors would not offset the costs in gasproducing and other sectors. Specifically, “every one per cent of future gas exports which is 
artificially re-directed towards the domestic market reduces GDP by an estimated \$150 million at 2025” (DAE 2013, piii).

To investigate these issues further, and to provide a more comprehensive analysis of the effects on downstream gas-users, a general-equilibrium analysis of Western Australia's domestic gas reservation policy will be undertaken in the future.

\section{Conclusions}

The domestic gas reservation policy is generally viewed as having the same effects as two separate distortions in the gas market, which are each detrimental to overall Australian living standards. The lower price that producers receive for gas sold on the domestic market acts as an implicit tax on producers. This lowers the incentive to invest in gas exploration and production, lowering overall activity in the domestic economy. The lower price that domestic consumers pay for gas acts as an implicit subsidy, resulting in an opportunity cost because the additional gas supplied to the domestic market is not put to its highest-value use. It shifts labour and capital into downstream, gas-intensive industries and away from other sectors of the economy, but this should be viewed as a diversion of resources towards lowervalue uses rather than a generation of new activity.

This paper improves on this two-part interpretation of the domestic gas reservation policy by developing an elemental model which explicitly recognises that the policy imposes a proportional relationship between export and domestic supply. However, the model is consistent with the standard interpretation, and shows how the implicit tax and subsidy rates are related to the proportion of gas reserved.

Based on IMO (2014) projections of domestic demand and production capacity, it is anticipated that a 15 per cent reservation policy would be binding in Western Australia for future LNG projects. The IMO forecasts low growth in domestic gas demand and expects the current excess capacity in the domestic gas market to continue to grow. In this environment, gas producers are likely to have little incentive to develop new sources of domestic supply in the absence of the reservation policy.

The modelling confirms that a binding reservation policy, such as Western Australia's, will always result in a deadweight loss. The Western Australian economy is worse off because some gas production will not go ahead and income is foregone by diverting some gas from exports to domestic supply. While the domestic gas reservation policy would expand activity 
in gas-using industries, this does not represent an overall benefit, particularly in the long run. The additional labour and capital attracted to these industries could also have been employed in other industries, where they would also earn income. There are also additional costs not captured in the model, such as the efficiency cost of requiring each project to supply 15 per cent to the domestic market, rather than only those projects whose cost of supplying the domestic market are lowest.

The work undertaken in this paper will be extended in future research. A project-by-project economic model of the Australian natural gas industry is under development to evaluate the economic impacts of the domestic gas reservation policy, as well as other issues facing the industry. This work is adding detail and quantitative estimates to the conceptual approach in this paper. Further extension is via incorporation into a nation-wide computable general equilibrium model to quantify the flow-on effects to other industries and the broader economy. 


\section{References}

ACIL Allen 2014, Domgas Reservation Policy: review of literature and policy

recommendations, report to Regulation Authority of Western Australia, March.

Apache 2013, Devil Creek Gas Plant Operations Fact Sheet, August.

http://www.apachecorp.com/Resources/Upload/file/AEL/AEL_Devil_Creek_Fact_Sheet_201 308.pdf, accessed 3 March 2015.

APPEA, Australian Petroleum Production \& Exploration Association 2014, Australian LNG

Projects, accessed 5/11/2014, <http://www.appea.com.au/oil-gas-

explained/operation/australian-lng-projects/> .

BHP Billiton 2013, BHP Billiton Celebrates First Gas at Macedon, 20 September 2013.

http://www.bhpbilliton.com/home/investors/news/Documents/2013/130920_petroleumpotash _australiaproductionunit_macedon_BHPBillitonCelebratesFirstGasatMacedon.pdf, accessed 3 March 2015.

Bureau of Resources and Energy Economics and Department of Industry (BREE) 2013, Gas Market Report, Canberra.

Bureau of Resources and Energy Economics and Department of Industry, (BREE) 2014a, Eastern Australian Domestic Gas Market Study, Canberra.

Bureau of Resources and Energy Economics (BREE) 2014b, Gas Market Report 2014, Canberra, November.

Bureau of Resources and Energy Economics (BREE) 2014c Australian Energy Statistics, Canberra, July.

Deloitte Access Economics 2013, The Economic Impacts of a Domestic Gas Reservation Policy, report to Australian Petroleum Production and Exploration Association Limited.

Economic Regulation Authority (ERA) 2014, Inquiry into Microeconomic Reform in Western Australia: Final Report, Perth.

Gohin, A. and Moschini, GianCarlo, 'Evaluating the Market and Welfare Impacts of Agricultural Policies in Developed Countries: Comparison of Partial and General Equilibrium Measures’, Review of Agricultural Economics, Vol. 28, No. 2, pp 195-211. 
Gulen, H. and M. Ion (2013), 'Policy Uncertainty and Corporate Investment', SSRN Working Paper Series, December 2012.

Independent Market Operator (IMO) 2013, Gas Statement of Opportunities, Perth, July. Independent Market Operator (IMO) 2014, Gas Statement of Opportunities, Perth, December. Inpex 2015, Ichthys in detail, http://www.inpex.com.au/our-projects/ichthys-lngproject/ichthys-in-detail/project-facilities/, accessed 13 March 2015.

Ledesma, D, J. Henderson and N. Palmer (2014), The Future of Australian LNG Exports: will domestic challenges limit the development of future LNG export capacity?, The Oxford Institute for Energy Studies, September.

Parliament of Western Australia, Economics and Industry Standing Committee 2011, Inquiry into domestic gas prices, Report No. 6 in the $38^{\text {th }}$ Parliament, Perth.

Pastor, L and P. Veronesi (2012), 'Uncertainty about Government Policy and Stock Prices’, The Journal of Finance, Vol. 67, No. 4, pp. 1219-64.

Western Australian Department of Mines and Petroleum 2014, Statistics Digest Resources Data Files.

Western Australian Government 2014, State gets new domestic NWS gas commitment, media release, Perth, accessed 25 March 2015, http://www.mediastatements.wa.gov.au/pages/StatementDetails.aspx?listName=StatementsB arnett\&StatId=8849.

Wood, T. Carter, L. and Mullerworth, D. 2013, Getting gas right: Australia’s energy challenge, Grattan Institute. 


\section{Figures}

Figure A: Western Australian Domestic Gas Prices, \$AUD per GJ

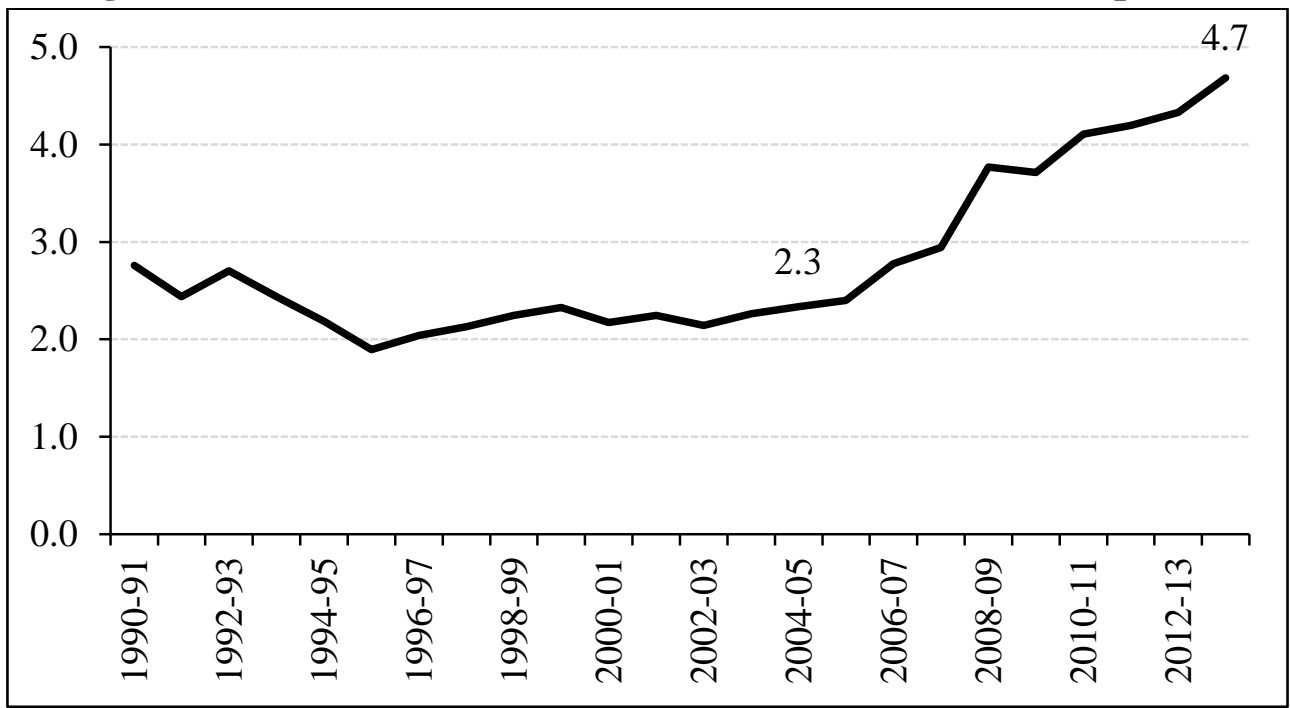

Source: WA Department of Mines and Petroleum, Statistics Digest Resources Data Files, 2014

Figure B: Undistorted gas market

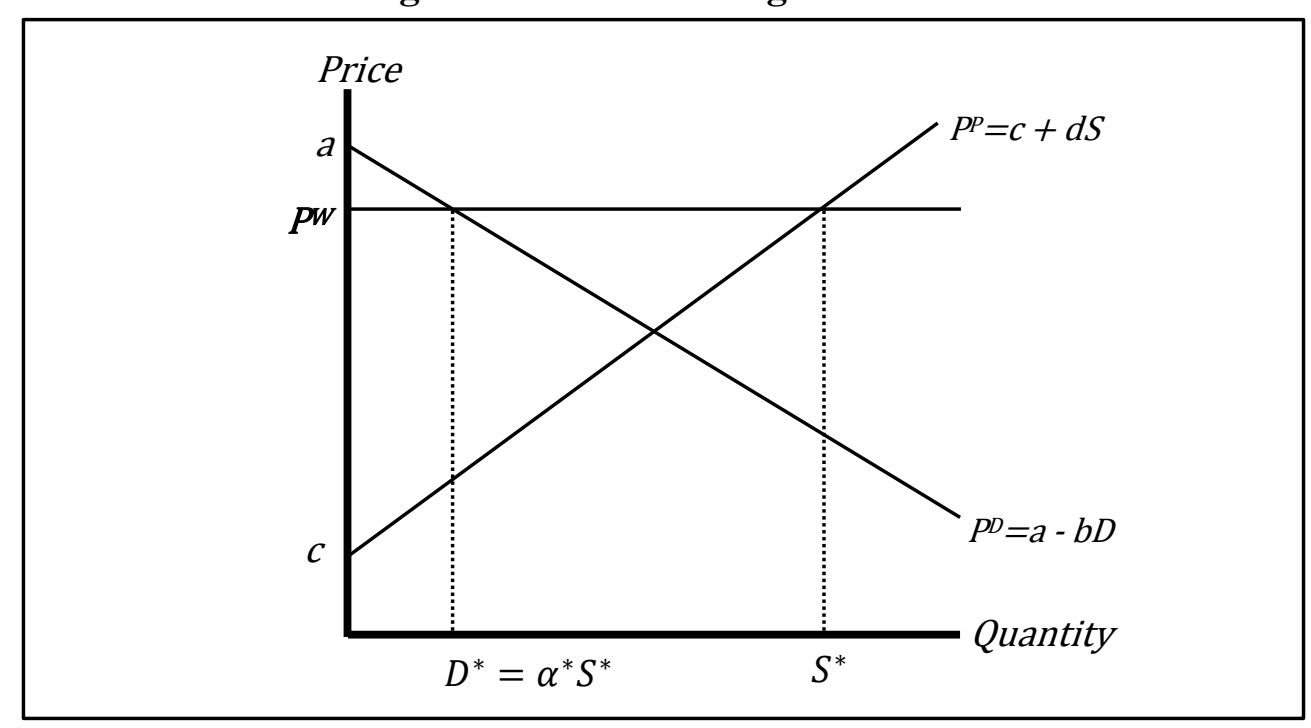


Figure C: domestic supply curve under the reservation policy

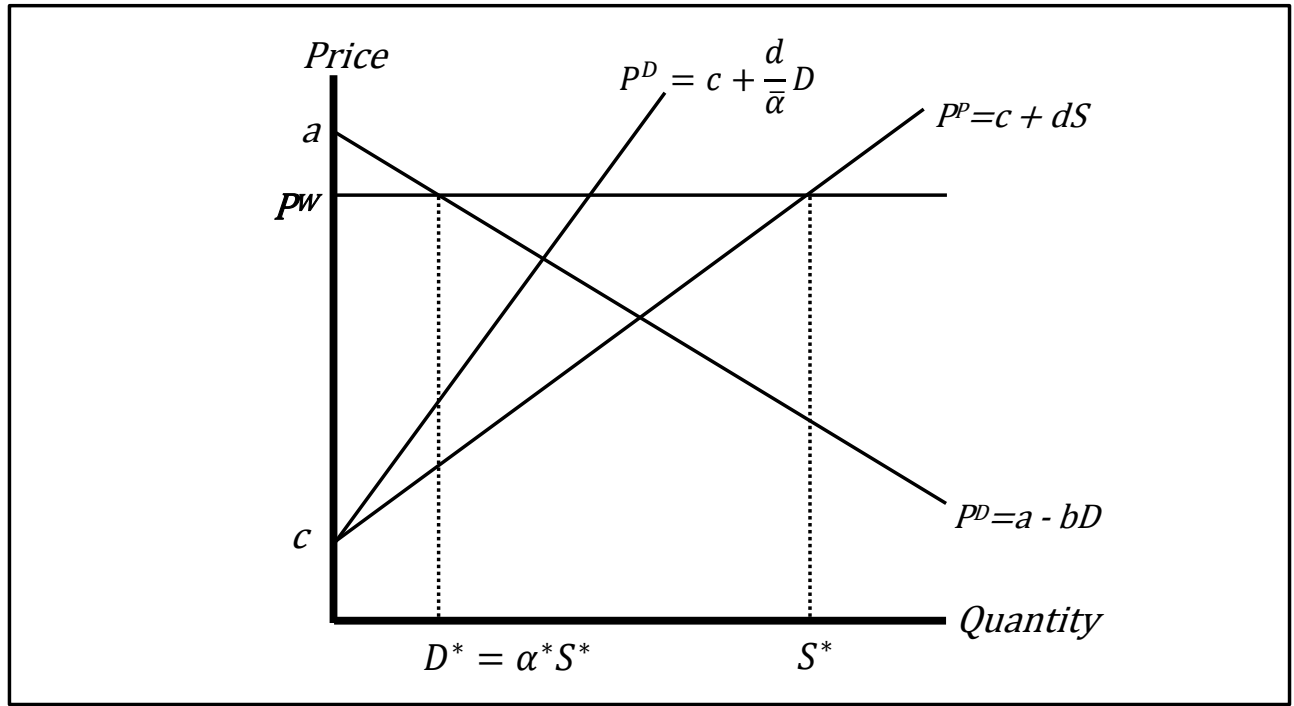

Figure D: gas market under the domestic reservation policy

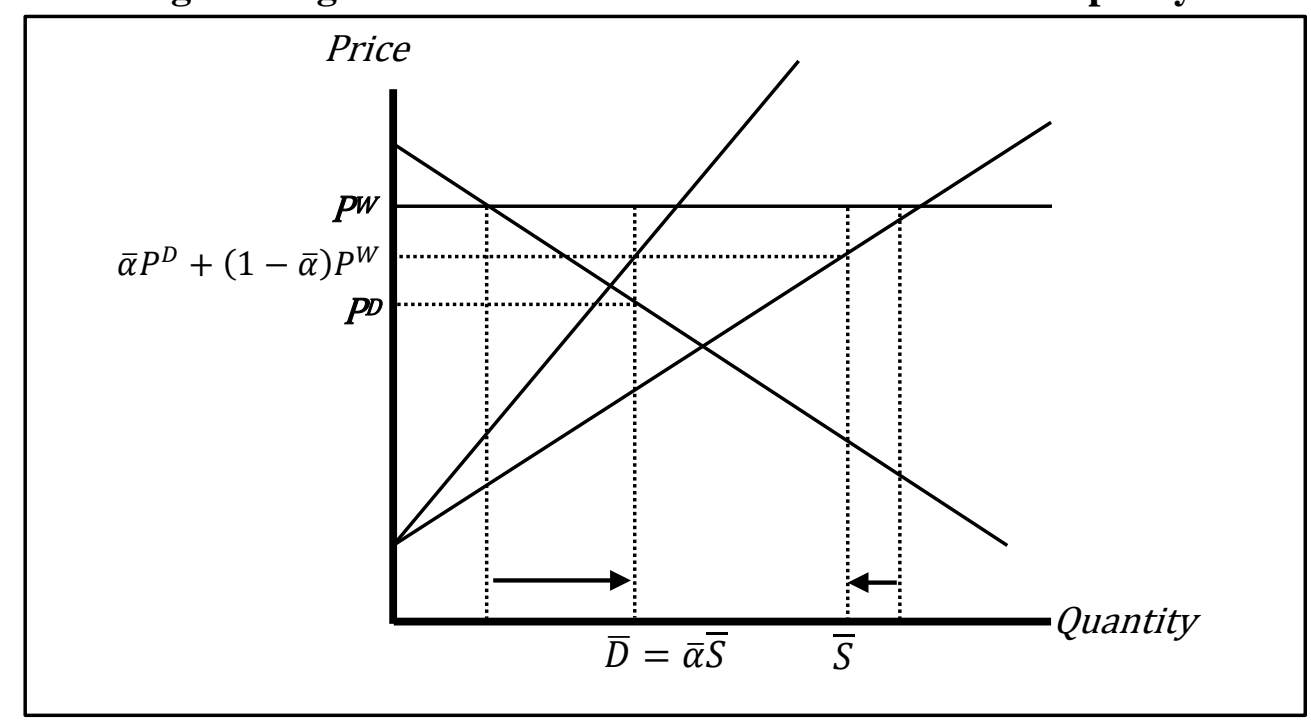


Figure E: gas market under the domestic reservation policy

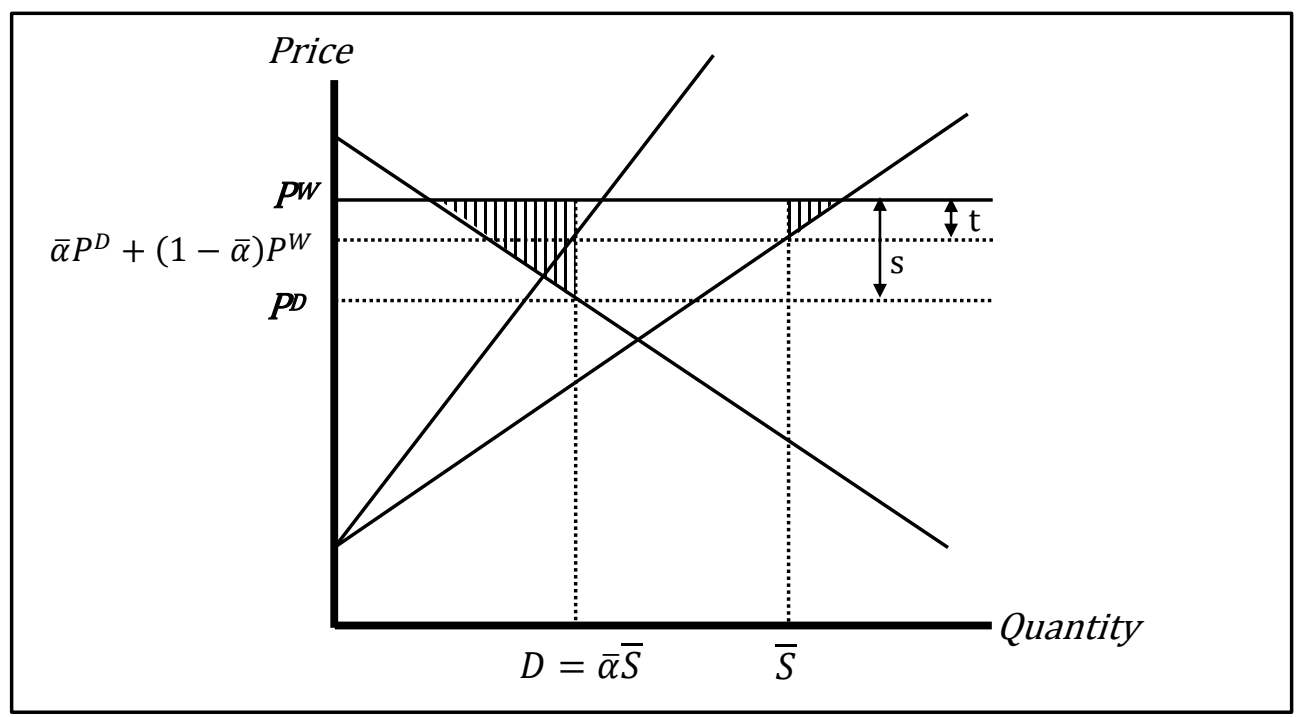

Figure F: Share of domestic gas consumption in total gas production, Western Australia

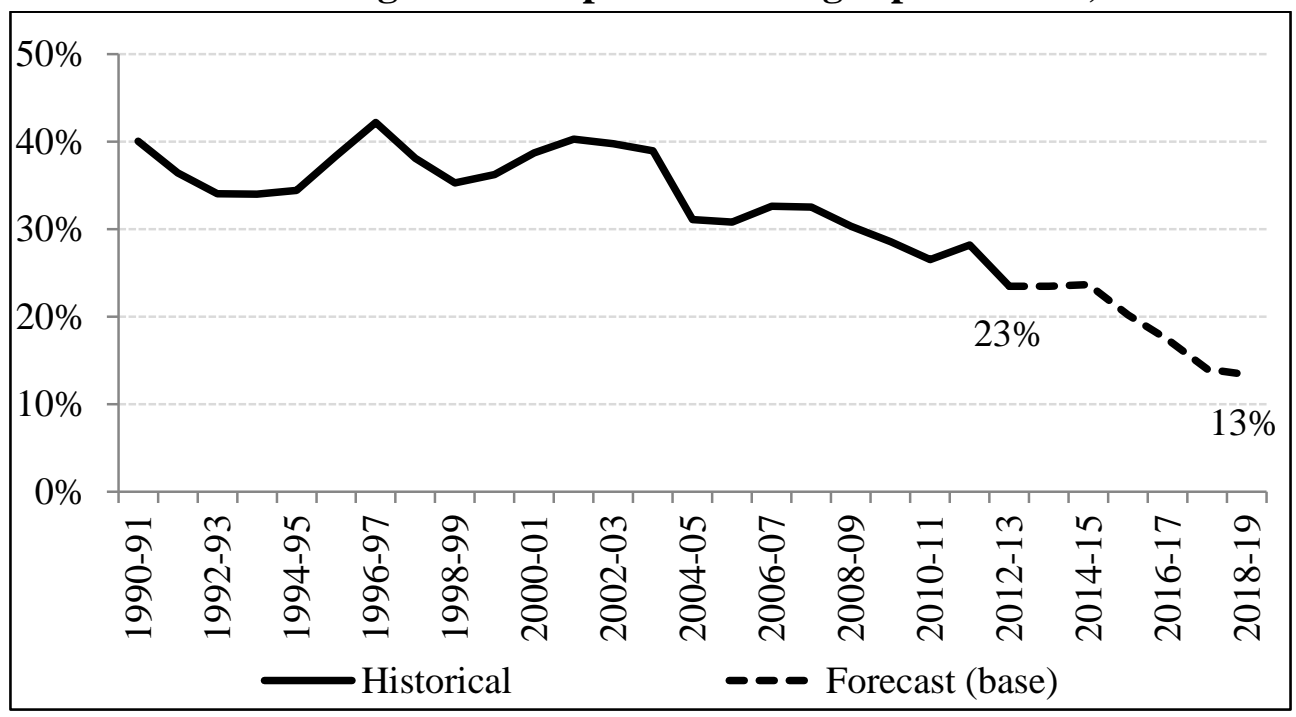

Source: Production: BREE Australian Energy Statistics 2014 and Consumption: IMO 2014 Note: consumption data excludes gas used in LNG processing 
Figure G: Domestic gas capacity and demand in Western Australia (TJ per day)

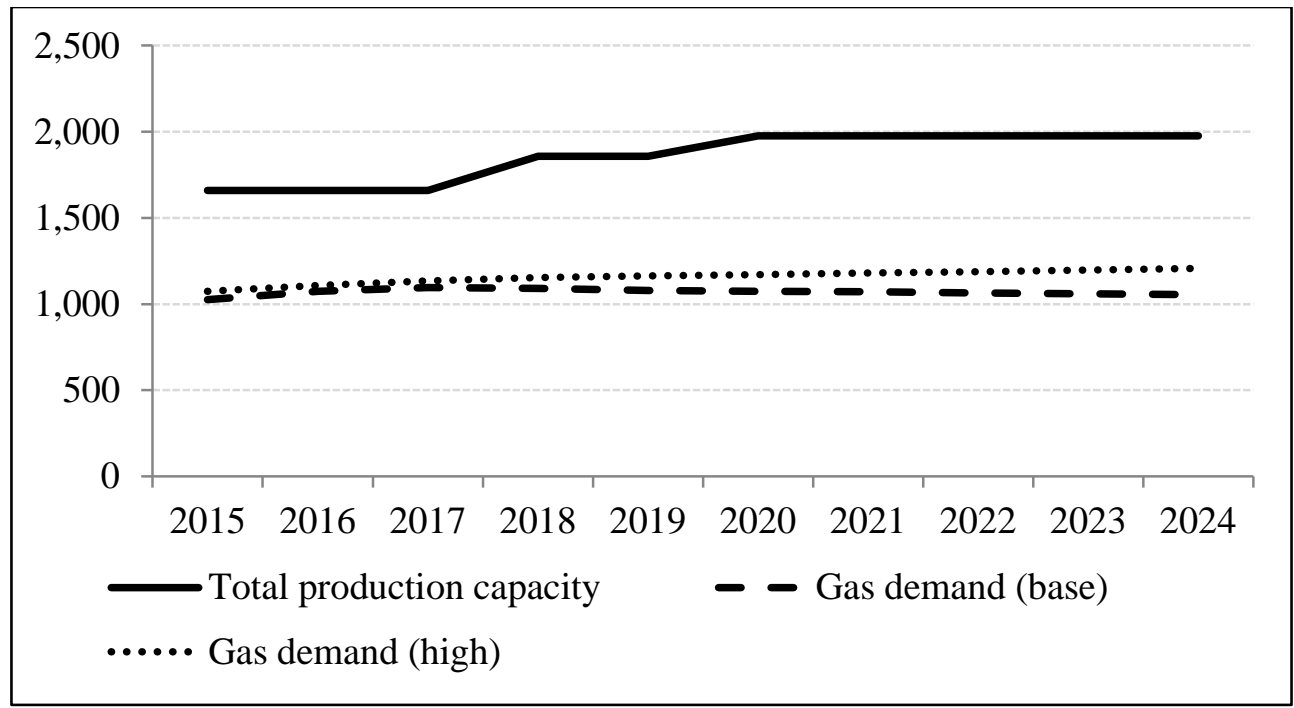

Source: IMO 2014

Figure H: Share of domestic gas consumption by industry, Western Australia

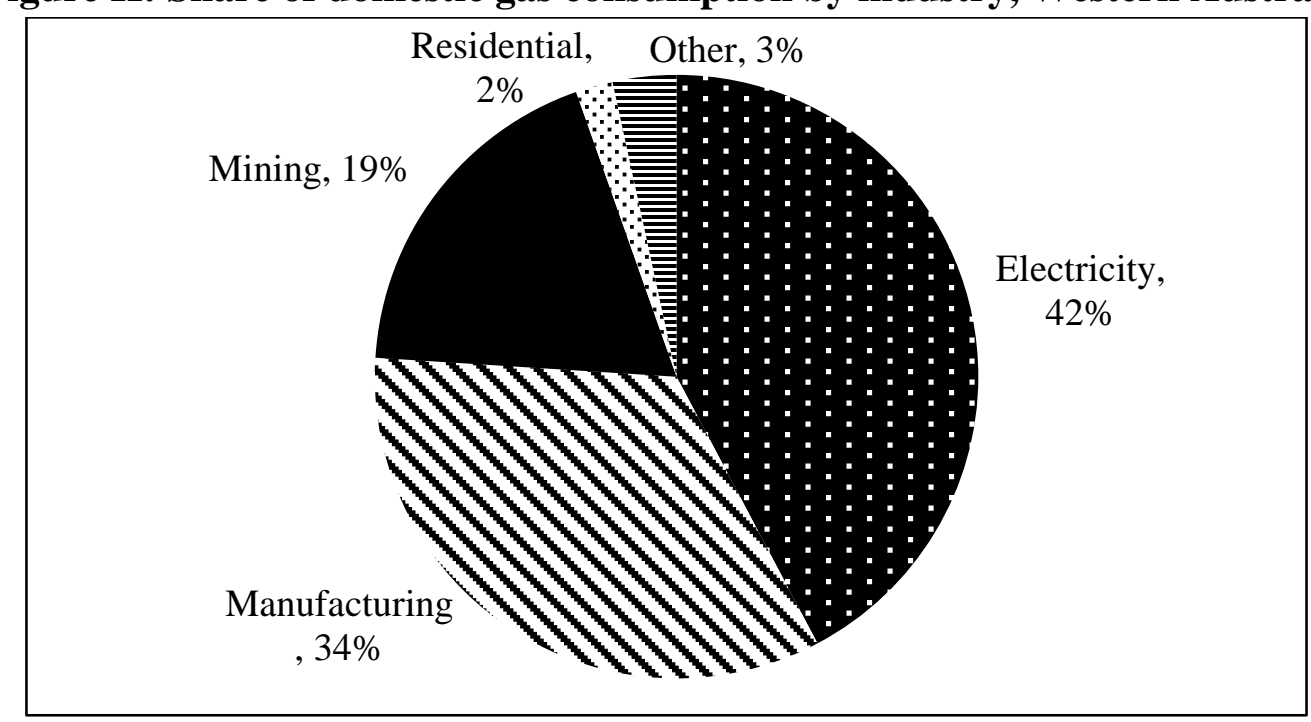

Source: BREE Australian Energy Statistics 2014 
Figure A1: Gas market under the domestic reservation policy

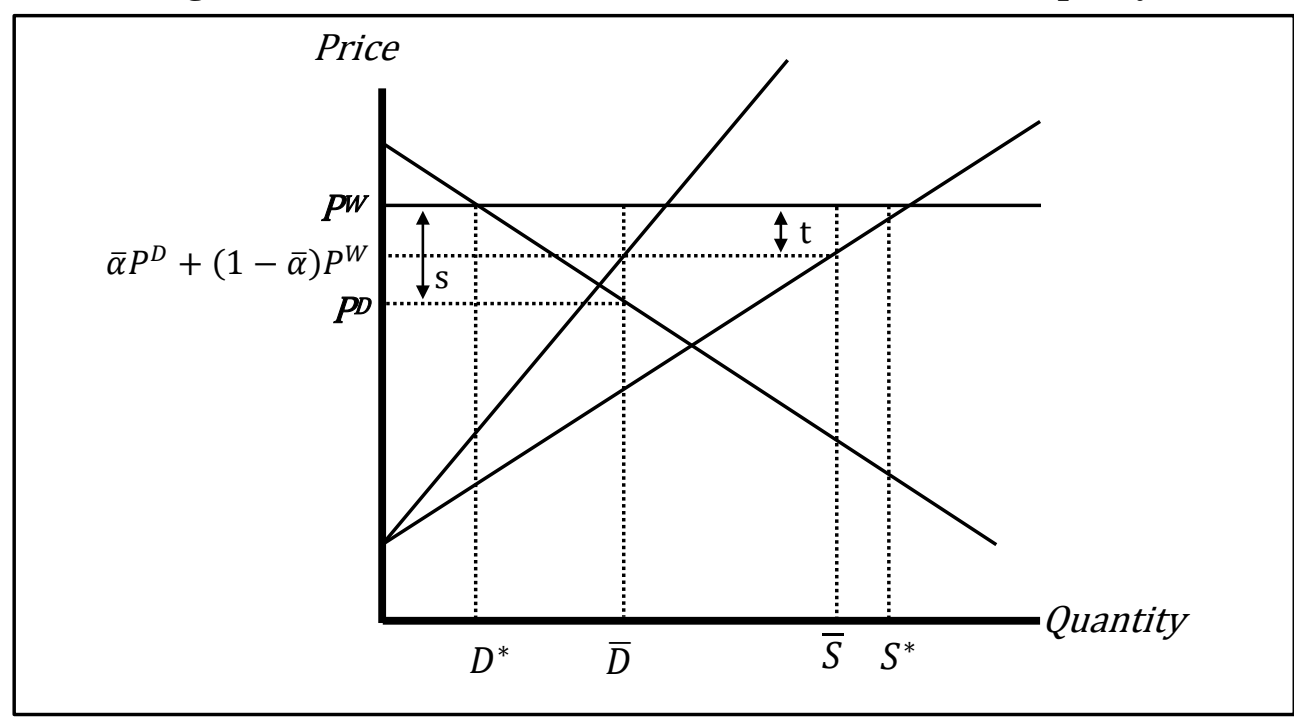




\section{Appendix}

This appendix presents further detail on the implied tax and subsidy rates as well the formula for the deadweight loss.

\section{$\mathbf{P}^{\mathrm{D}}$ is lower than $\mathbf{P}^{\mathrm{W}}$ under domestic gas reservation}

To show that the domestic price, $\mathrm{P}^{\mathrm{D}}$, is lower than the export price, $\mathrm{P}^{\mathrm{W}}$, under the reservation policy, the relationship between $\mathrm{P}^{\mathrm{D}}, \mathrm{P}^{\mathrm{W}}, \alpha^{*}$ and $\bar{\alpha}$ is required. From the demand curve, $P^{D}=a-b \bar{\alpha} \bar{S}$, in the presence of the gas reservation policy, so substituting in the condition for $\bar{S}$ from equation (9) gives:

$$
P^{D}\left(1+\frac{b}{d} \bar{\alpha}^{2}\right)=a+c \frac{b}{d} \bar{\alpha}-\frac{b}{d} \bar{\alpha}(1-\bar{\alpha}) P^{W}
$$

Equation (6) can be rearranged to find the parameter $a$, and substituting this into equation A1 yields:

$$
P^{D}=P^{W}+\frac{b / d}{\left(1+b / d \bar{\alpha}^{2}\right)}\left(\alpha^{*}-\bar{\alpha}\right)\left(P^{W}-c\right)
$$

The term $\left(P^{W}-c\right)$ is always positive for a gas market where it is worthwhile to produce the first unit of gas. This equation implies that $P^{D}$ will be less than $P^{W}$ whenever the domestic gas reservation policy is binding, or $\bar{\alpha}>\alpha^{*}$. Also note that when $\bar{\alpha}=\alpha^{*}$, then $P^{D}$ will equal $P^{W}$, as in the undistorted market.

\section{Implicit tax and subsidy rates}

The implicit production tax rate, $t$, associated with the domestic gas reservation policy is the percent difference between the world price and the producer price (which is the weighted average of the domestic and international prices received by the gas producers). That is:

$$
P^{W}(1-t)=\bar{\alpha} P^{D}+(1-\bar{\alpha}) P^{W}
$$

The formula for the domestic price, as in (A2), can then be used to find the implicit tax rate as a percent of the world price.

$$
t=\frac{b / d}{\left(1+b / d \bar{\alpha}^{2}\right)} \bar{\alpha}\left(\bar{\alpha}-\alpha^{*}\right)\left(1-\frac{c}{P^{W}}\right)
$$

So when the reservation policy is binding, or $\bar{\alpha}>\alpha^{*}$, the implicit tax rate is positive. 
On the other hand, the consumption subsidy rate, $s$, associated with the domestic gas reservation policy is the percent difference between the world and domestic consumer prices.

$$
P^{D}=P^{W}(1-s)
$$

Again, substituting in equation A2 gives a formula for the implicit subsidy rate as a percent of the world price.

$$
s=\frac{b / d}{\left(1+b / d \bar{\alpha}^{2}\right)}\left(\bar{\alpha}-\alpha^{*}\right)\left(1-\frac{c}{P^{W}}\right)
$$

So when the reservation policy is binding, or $\bar{\alpha}>\alpha^{*}$, the implicit subsidy rate is positive. Comparing equations A4 and A6 shows that $t=\bar{\alpha} s$ as in equation (10).

\section{Deadweight loss}

The deadweight loss from the imposition of the domestic gas reservation policy is the loss in producer surplus, net of any gain in consumer surplus.

Figure A1 shows the undistorted equilibrium, denoted by an asterix, and the equilibrium in the presence of the domestic gas reservation policy, denoted by a bar. The implicit tax and subsidy rates are also marked.

\section{[Insert Figure A1]}

The loss in producer surplus, $\Delta P S$, is the loss from reduced production volumes plus the loss from accepting a lower price on their domestic supply. That is,

$$
\Delta P S=s \bar{D}+t \frac{1}{2}\left(S^{*}-\bar{S}\right)
$$

Likewise, the gain in consumer surplus, $\Delta C S$, is the gain from the price reduction on gas consumed in the absence of the reservation policy, plus the gain from additional gas consumption in the presence of the policy.

$$
\Delta C S=s D^{*}+s \frac{1}{2}\left(\bar{D}-D^{*}\right)
$$

Overall, the deadweight loss is:

$$
\Delta C S-\Delta P S=\frac{t}{2} S^{*}\left(\frac{\alpha^{*}}{\bar{\alpha}}-1\right)
$$

The deadweight loss is negative whenever the reservation policy is binding, $\bar{\alpha}>\alpha^{*}$, and so the reservation policy will reduce the overall surplus in the gas sector. 
Editor, UWA Economics Discussion Papers:

Sam Hak Kan Tang

University of Western Australia

35 Sterling Hwy

Crawley WA 6009

Australia

Email: ecoadmin@biz.uwa.edu.au

The Economics Discussion Papers are available at:

1980 - 2002: http://ecompapers.biz.uwa.edu.au/paper/PDF\%20of\%20Discussion\%20Papers/

Since 2001: http://ideas.repec.org/s/uwa/wpaper1.html

Since 2004: http://www.business.uwa.edu.au/school/disciplines/economics

\begin{tabular}{|c|c|c|}
\hline \multicolumn{3}{|c|}{$\begin{array}{l}\text { ECONOMICS DISCUSSION PAPERS } \\
2013\end{array}$} \\
\hline $\begin{array}{l}\text { DP } \\
\text { NUMBER }\end{array}$ & AUTHORS & TITLE \\
\hline 13.01 & $\begin{array}{l}\text { Chen, M., Clements, K.W. and } \\
\text { Gao, G. }\end{array}$ & THREE FACTS ABOUT WORLD METAL PRICES \\
\hline 13.02 & Collins, J. and Richards, O. & $\begin{array}{l}\text { EVOLUTION, FERTILITY AND THE AGEING } \\
\text { POPULATION }\end{array}$ \\
\hline 13.03 & $\begin{array}{l}\text { Clements, K., Genberg, H., } \\
\text { Harberger, A., Lothian, J., } \\
\text { Mundell, R., Sonnenschein, H. and } \\
\text { Tolley, G. }\end{array}$ & LARRY SJAASTAD, 1934-2012 \\
\hline 13.04 & Robitaille, M.C. and Chatterjee, I. & MOTHERS-IN-LAW AND SON PREFERENCE IN INDIA \\
\hline 13.05 & Clements, K.W. and Izan, I.H.Y. & $\begin{array}{l}\text { REPORT ON THE } 25^{\mathrm{TH}} \text { PHD CONFERENCE IN } \\
\text { ECONOMICS AND BUSINESS }\end{array}$ \\
\hline 13.06 & Walker, A. and Tyers, R. & QUANTIFYING AUSTRALIA’S “THREE SPEED” BOOM \\
\hline 13.07 & Yu, F. and Wu, Y. & PATENT EXAMINATION AND DISGUISED PROTECTION \\
\hline 13.08 & Yu, F. and Wu, Y. & $\begin{array}{l}\text { PATENT CITATIONS AND KNOWLEDGE SPILLOVERS: } \\
\text { AN ANALYSIS OF CHINESE PATENTS REGISTER IN } \\
\text { THE US }\end{array}$ \\
\hline 13.09 & Chatterjee, I. and Saha, B. & BARGAINING DELEGATION IN MONOPOLY \\
\hline 13.10 & Cheong, T.S. and Wu, Y. & $\begin{array}{l}\text { GLOBALIZATION AND REGIONAL INEQUALITY IN } \\
\text { CHINA }\end{array}$ \\
\hline 13.11 & Cheong, T.S. and Wu, Y. & INEQUALITY AND CRIME RATES IN CHINA \\
\hline 13.12 & Robertson, P.E. and Ye, L. & ON THE EXISTENCE OF A MIDDLE INCOME TRAP \\
\hline 13.13 & Robertson, P.E. & THE GLOBAL IMPACT OF CHINA’S GROWTH \\
\hline 13.14 & $\begin{array}{l}\text { Hanaki, N., Jacquemet, N., } \\
\text { Luchini, S., and Zylbersztejn, A. }\end{array}$ & $\begin{array}{l}\text { BOUNDED RATIONALITY AND STRATEGIC } \\
\text { UNCERTAINTY IN A SIMPLE DOMINANCE SOLVABLE } \\
\text { GAME }\end{array}$ \\
\hline 13.15 & $\begin{array}{l}\text { Okatch, Z., Siddique, A. and } \\
\text { Rammohan, A. }\end{array}$ & $\begin{array}{l}\text { DETERMINANTS OF INCOME INEQUALITY IN } \\
\text { BOTSWANA }\end{array}$ \\
\hline 13.16 & Clements, K.W. and Gao, G. & $\begin{array}{l}\text { A MULTI-MARKET APPROACH TO MEASURING THE } \\
\text { CYCLE }\end{array}$ \\
\hline
\end{tabular}




\begin{tabular}{|c|c|c|}
\hline 13.17 & Chatterjee, I. and Ray, R. & $\begin{array}{l}\text { THE ROLE OF INSTITUTIONS IN THE INCIDENCE OF } \\
\text { CRIME AND CORRUPTION }\end{array}$ \\
\hline 13.18 & Fu, D. and Wu, Y. & $\begin{array}{l}\text { EXPORT SURVIVAL PATTERN AND DETERMINANTS } \\
\text { OF CHINESE MANUFACTURING FIRMS }\end{array}$ \\
\hline 13.19 & Shi, X., Wu, Y. and Zhao, D. & $\begin{array}{l}\text { KNOWLEDGE INTENSIVE BUSINESS SERVICES AND } \\
\text { THEIR IMPACT ON INNOVATION IN CHINA }\end{array}$ \\
\hline 13.20 & $\begin{array}{l}\text { Tyers, R., Zhang, Y. and } \\
\text { Cheong, T.S. }\end{array}$ & $\begin{array}{l}\text { CHINA'S SAVING AND GLOBAL ECONOMIC } \\
\text { PERFORMANCE }\end{array}$ \\
\hline 13.21 & Collins, J., Baer, B. and Weber, E.J. & $\begin{array}{l}\text { POPULATION, TECHNOLOGICAL PROGRESS AND THE } \\
\text { EVOLUTION OF INNOVATIVE POTENTIAL }\end{array}$ \\
\hline 13.22 & Hartley, P.R. & THE FUTURE OF LONG-TERM LNG CONTRACTS \\
\hline 13.23 & Tyers, R. & $\begin{array}{l}\text { A SIMPLE MODEL TO STUDY GLOBAL } \\
\text { MACROECONOMIC INTERDEPENDENCE }\end{array}$ \\
\hline 13.24 & McLure, M. & $\begin{array}{l}\text { REFLECTIONS ON THE QUANTITY THEORY: PIGOU IN } \\
1917 \text { AND PARETO IN 1920-21 }\end{array}$ \\
\hline 13.25 & Chen, A. and Groenewold, N. & $\begin{array}{l}\text { REGIONAL EFFECTS OF AN EMISSIONS-REDUCTION } \\
\text { POLICY IN CHINA: THE IMPORTANCE OF THE } \\
\text { GOVERNMENT FINANCING METHOD }\end{array}$ \\
\hline 13.26 & Siddique, M.A.B. & $\begin{array}{l}\text { TRADE RELATIONS BETWEEN AUSTRALIA AND } \\
\text { THAILAND: } 1990 \text { TO } 2011\end{array}$ \\
\hline 13.27 & Li, B. and Zhang, J. & $\begin{array}{l}\text { GOVERNMENT DEBT IN AN INTERGENERATIONAL } \\
\text { MODEL OF ECONOMIC GROWTH, ENDOGENOUS } \\
\text { FERTILITY, AND ELASTIC LABOR WITH AN } \\
\text { APPLICATION TO JAPAN }\end{array}$ \\
\hline 13.28 & Robitaille, M. and Chatterjee, I. & $\begin{array}{l}\text { SEX-SELECTIVE ABORTIONS AND INFANT } \\
\text { MORTALITY IN INDIA: THE ROLE OF PARENTS' } \\
\text { STATED SON PREFERENCE }\end{array}$ \\
\hline 13.29 & Ezzati, P. & $\begin{array}{l}\text { ANALYSIS OF VOLATILITY SPILLOVER EFFECTS: } \\
\text { TWO-STAGE PROCEDURE BASED ON A MODIFIED } \\
\text { GARCH-M }\end{array}$ \\
\hline 13.30 & Robertson, P. E. & $\begin{array}{l}\text { DOES A FREE MARKET ECONOMY MAKE AUSTRALIA } \\
\text { MORE OR LESS SECURE IN A GLOBALISED WORLD? }\end{array}$ \\
\hline 13.31 & $\begin{array}{l}\text { Das, S., Ghate, C. and } \\
\text { Robertson, P. E. }\end{array}$ & $\begin{array}{l}\text { REMOTENESS AND UNBALANCED GROWTH: } \\
\text { UNDERSTANDING DIVERGENCE ACROSS INDIAN } \\
\text { DISTRICTS }\end{array}$ \\
\hline 13.32 & Robertson, P.E. and Sin, A. & $\begin{array}{l}\text { MEASURING HARD POWER: CHINA’S ECONOMIC } \\
\text { GROWTH AND MILITARY CAPACITY }\end{array}$ \\
\hline 13.33 & $\mathrm{Wu}, \mathrm{Y}$. & $\begin{array}{l}\text { TRENDS AND PROSPECTS FOR THE RENEWABLE } \\
\text { ENERGY SECTOR IN THE EAS REGION }\end{array}$ \\
\hline 13.34 & $\begin{array}{l}\text { Yang, S., Zhao, D., Wu, Y. and } \\
\text { Fan, J. }\end{array}$ & $\begin{array}{l}\text { REGIONAL VARIATION IN CARBON EMISSION AND } \\
\text { ITS DRIVING FORCES IN CHINA: AN INDEX } \\
\text { DECOMPOSITION ANALYSIS }\end{array}$ \\
\hline
\end{tabular}




\begin{tabular}{|c|c|c|}
\hline \multicolumn{3}{|c|}{$\begin{array}{l}\text { ECONOMICS DISCUSSION PAPERS } \\
2014\end{array}$} \\
\hline $\begin{array}{l}\text { DP } \\
\text { NUMBER }\end{array}$ & AUTHORS & TITLE \\
\hline 14.01 & $\begin{array}{l}\text { Boediono, Vice President of the Republic } \\
\text { of Indonesia }\end{array}$ & $\begin{array}{l}\text { THE CHALLENGES OF POLICY MAKING IN A } \\
\text { YOUNG DEMOCRACY: THE CASE OF INDONESIA } \\
\text { (52ND SHANN MEMORIAL LECTURE, 2013) }\end{array}$ \\
\hline 14.02 & Metaxas, P.E. and Weber, E.J. & $\begin{array}{l}\text { AN AUSTRALIAN CONTRIBUTION TO } \\
\text { INTERNATIONAL TRADE THEORY: THE } \\
\text { DEPENDENT ECONOMY MODEL }\end{array}$ \\
\hline 14.03 & Fan, J., Zhao, D., Wu, Y. and Wei, J. & $\begin{array}{l}\text { CARBON PRICING AND ELECTRICITY MARKET } \\
\text { REFORMS IN CHINA }\end{array}$ \\
\hline 14.04 & McLure, M. & $\begin{array}{l}\text { A.C. PIGOU'S MEMBERSHIP OF THE } \\
\text { 'CHAMBERLAIN-BRADBURY’ COMMITTEE. } \\
\text { PART I: THE HISTORICAL CONTEXT }\end{array}$ \\
\hline 14.05 & McLure, M. & $\begin{array}{l}\text { A.C. PIGOU’S MEMBERSHIP OF THE } \\
\text { 'CHAMBERLAIN-BRADBURY’ COMMITTEE. } \\
\text { PART II: ‘TRANSITIONAL’AND ‘ONGOING' ISSUES }\end{array}$ \\
\hline 14.06 & King, J.E. and McLure, M. & HISTORY OF THE CONCEPT OF VALUE \\
\hline 14.07 & Williams, A. & $\begin{array}{l}\text { A GLOBAL INDEX OF INFORMATION AND } \\
\text { POLITICAL TRANSPARENCY }\end{array}$ \\
\hline 14.08 & Knight, K. & $\begin{array}{l}\text { A.C. PIGOU'S THE THEORY OF UNEMPLOYMENT } \\
\text { AND ITS CORRIGENDA: THE LETTERS OF } \\
\text { MAURICE ALLEN, ARTHUR L. BOWLEY, RICHARD } \\
\text { KAHN AND DENNIS ROBERTSON }\end{array}$ \\
\hline 14.09 & Cheong, T.S. and Wu, Y. & $\begin{array}{l}\text { THE IMPACTS OF STRUCTURAL RANSFORMATION } \\
\text { AND INDUSTRIAL UPGRADING ON REGIONAL } \\
\text { INEQUALITY IN CHINA }\end{array}$ \\
\hline 14.10 & $\begin{array}{l}\text { Chowdhury, M.H., Dewan, M.N.A., } \\
\text { Quaddus, M., Naude, M. and } \\
\text { Siddique, A. }\end{array}$ & $\begin{array}{l}\text { GENDER EQUALITY AND SUSTAINABLE } \\
\text { DEVELOPMENT WITH A FOCUS ON THE COASTAL } \\
\text { FISHING COMMUNITY OF BANGLADESH }\end{array}$ \\
\hline 14.11 & Bon, J. & $\begin{array}{l}\text { UWA DISCUSSION PAPERS IN ECONOMICS: THE } \\
\text { FIRST } 750\end{array}$ \\
\hline 14.12 & Finlay, K. and Magnusson, L.M. & $\begin{array}{l}\text { BOOTSTRAP METHODS FOR INFERENCE WITH } \\
\text { CLUSTER-SAMPLE IV MODELS }\end{array}$ \\
\hline 14.13 & Chen, A. and Groenewold, N. & $\begin{array}{l}\text { THE EFFECTS OF MACROECONOMIC SHOCKS ON } \\
\text { THE DISTRIBUTION OF PROVINCIAL OUTPUT IN } \\
\text { CHINA: ESTIMATES FROM A RESTRICTED VAR } \\
\text { MODEL }\end{array}$ \\
\hline 14.14 & Hartley, P.R. and Medlock III, K.B. & $\begin{array}{l}\text { THE VALLEY OF DEATH FOR NEW ENERGY } \\
\text { TECHNOLOGIES }\end{array}$ \\
\hline 14.15 & $\begin{array}{l}\text { Hartley, P.R., Medlock III, K.B., } \\
\text { Temzelides, T. and Zhang, X. }\end{array}$ & $\begin{array}{l}\text { LOCAL EMPLOYMENT IMPACT FROM COMPETING } \\
\text { ENERGY SOURCES: SHALE GAS VERSUS WIND } \\
\text { GENERATION IN TEXAS }\end{array}$ \\
\hline 14.16 & Tyers, R. and Zhang, Y. & $\begin{array}{l}\text { SHORT RUN EFFECTS OF THE ECONOMIC REFORM } \\
\text { AGENDA }\end{array}$ \\
\hline 14.17 & Clements, K.W., Si, J. and Simpson, T. & UNDERSTANDING NEW RESOURCE PROJECTS \\
\hline 14.18 & Tyers, R. & $\begin{array}{l}\text { SERVICE OLIGOPOLIES AND AUSTRALIA'S } \\
\text { ECONOMY-WIDE PERFORMANCE }\end{array}$ \\
\hline 14.19 & Tyers, R. and Zhang, Y. & $\begin{array}{l}\text { REAL EXCHANGE RATE DETERMINATION AND } \\
\text { THE CHINA PUZZLE }\end{array}$ \\
\hline
\end{tabular}




\begin{tabular}{|c|c|c|}
\hline \multicolumn{3}{|c|}{$\begin{array}{l}\text { ECONOMICS DISCUSSION PAPERS } \\
2014\end{array}$} \\
\hline $\begin{array}{l}\text { DP } \\
\text { NUMBER }\end{array}$ & AUTHORS & TITLE \\
\hline 14.20 & Ingram, S.R. & $\begin{array}{l}\text { COMMODITY PRICE CHANGES ARE } \\
\text { CONCENTRATED AT THE END OF THE CYCLE }\end{array}$ \\
\hline 14.21 & Cheong, T.S. and Wu, Y. & $\begin{array}{l}\text { CHINA'S INDUSTRIAL OUTPUT: A COUNTY-LEVEL } \\
\text { STUDY USING A NEW FRAMEWORK OF } \\
\text { DISTRIBUTION DYNAMICS ANALYSIS }\end{array}$ \\
\hline 14.22 & $\begin{array}{l}\text { Siddique, M.A.B., Wibowo, H. and } \\
\text { Wu, Y. }\end{array}$ & $\begin{array}{l}\text { FISCAL DECENTRALISATION AND INEQUALITY IN } \\
\text { INDONESIA: 1999-2008 }\end{array}$ \\
\hline 14.23 & Tyers, R. & $\begin{array}{l}\text { ASYMMETRY IN BOOM-BUST SHOCKS: } \\
\text { AUSTRALIAN PERFORMANCE WITH OLIGOPOLY }\end{array}$ \\
\hline 14.24 & Arora, V., Tyers, R. and Zhang, Y. & $\begin{array}{l}\text { RECONSTRUCTING THE SAVINGS GLUT: THE } \\
\text { GLOBAL IMPLICATIONS OF ASIAN EXCESS } \\
\text { SAVING }\end{array}$ \\
\hline 14.25 & Tyers, R. & $\begin{array}{l}\text { INTERNATIONAL EFFECTS OF CHINA'S RISE AND } \\
\text { TRANSITION: NEOCLASSICAL AND KEYNESIAN } \\
\text { PERSPECTIVES }\end{array}$ \\
\hline 14.26 & Milton, S. and Siddique, M.A.B. & $\begin{array}{l}\text { TRADE CREATION AND DIVERSION UNDER THE } \\
\text { THAILAND-AUSTRALIA FREE TRADE } \\
\text { AGREEMENT (TAFTA) }\end{array}$ \\
\hline 14.27 & Clements, K.W. and Li, L. & VALUING RESOURCE INVESTMENTS \\
\hline 14.28 & Tyers, R. & $\begin{array}{l}\text { PESSIMISM SHOCKS IN A MODEL OF GLOBAL } \\
\text { MACROECONOMIC INTERDEPENDENCE }\end{array}$ \\
\hline 14.29 & Iqbal, K. and Siddique, M.A.B. & $\begin{array}{l}\text { THE IMPACT OF CLIMATE CHANGE ON } \\
\text { AGRICULTURAL PRODUCTIVITY: EVIDENCE } \\
\text { FROM PANEL DATA OF BANGLADESH }\end{array}$ \\
\hline 14.30 & Ezzati, P. & $\begin{array}{l}\text { MONETARY POLICY RESPONSES TO FOREIGN } \\
\text { FINANCIAL MARKET SHOCKS: APPLICATION OF A } \\
\text { MODIFIED OPEN-ECONOMY TAYLOR RULE }\end{array}$ \\
\hline 14.31 & Tang, S.H.K. and Leung, C.K.Y. & $\begin{array}{l}\text { THE DEEP HISTORICAL ROOTS OF } \\
\text { MACROECONOMIC VOLATILITY }\end{array}$ \\
\hline 14.32 & Arthmar, R. and McLure, M. & $\begin{array}{l}\text { PIGOU, DEL VECCHIO AND SRAFFA: THE } 1955 \\
\text { INTERNATIONAL ‘ANTONIO FELTRINELLI’ PRIZE } \\
\text { FOR THE ECONOMIC AND SOCIAL SCIENCES }\end{array}$ \\
\hline 14.33 & McLure, M. & $\begin{array}{l}\text { A-HISTORIAL ECONOMIC DYNAMICS: A BOOK } \\
\text { REVIEW }\end{array}$ \\
\hline 14.34 & Clements, K.W. and Gao, G. & $\begin{array}{l}\text { THE ROTTERDAM DEMAND MODEL HALF A } \\
\text { CENTURY ON }\end{array}$ \\
\hline
\end{tabular}




\begin{tabular}{|c|c|c|}
\hline \multicolumn{3}{|c|}{$\begin{array}{c}\text { ECONOMICS DISCUSSION PAPERS } \\
2015\end{array}$} \\
\hline $\begin{array}{l}\text { DP } \\
\text { NUMBER }\end{array}$ & AUTHORS & TITLE \\
\hline 15.01 & Robertson, P.E. and Robitaille, M.C. & $\begin{array}{l}\text { THE GRAVITY OF RESOURCES AND THE } \\
\text { TYRANNY OF DISTANCE }\end{array}$ \\
\hline 15.02 & Tyers, R. & $\begin{array}{l}\text { FINANCIAL INTEGRATION AND CHINA'S GLOBAL } \\
\text { IMPACT }\end{array}$ \\
\hline 15.03 & Clements, K.W. and Si, J. & $\begin{array}{l}\text { MORE ON THE PRICE-RESPONSIVENESS OF FOOD } \\
\text { CONSUMPTION }\end{array}$ \\
\hline 15.04 & Tang, S.H.K. & $\begin{array}{l}\text { PARENTS, MIGRANT DOMESTIC WORKERS, AND } \\
\text { CHILDREN'S SPEAKING OF A SECOND } \\
\text { LANGUAGE: EVIDENCE FROM HONG KONG }\end{array}$ \\
\hline 15.05 & Tyers, R. & $\begin{array}{l}\text { CHINA AND GLOBAL MACROECONOMIC } \\
\text { INTERDEPENDENCE }\end{array}$ \\
\hline 15.06 & $\begin{array}{l}\text { Fan, J., Wu, Y., Guo, X., Zhao, D. and } \\
\text { Marinova, D. }\end{array}$ & $\begin{array}{l}\text { REGIONAL DISPARITY OF EMBEDDED CARBON } \\
\text { FOOTPRINT AND ITS SOURCES IN CHINA: A } \\
\text { CONSUMPTION PERSPECTIVE }\end{array}$ \\
\hline 15.07 & $\begin{array}{l}\text { Fan, J., Wang, S., Wu, Y., Li, J. and } \\
\text { Zhao, D. }\end{array}$ & $\begin{array}{l}\text { BUFFER EFFECT AND PRICE EFFECT OF A } \\
\text { PERSONAL CARBON TRADING SCHEME }\end{array}$ \\
\hline 15.08 & Neill, K. & $\begin{array}{l}\text { WESTERN AUSTRALIA'S DOMESTIC GAS } \\
\text { RESERVATION POLICY THE ELEMENTAL } \\
\text { ECONOMICS }\end{array}$ \\
\hline 15.09 & Collins, J., Baer, B. and Weber, E.J. & $\begin{array}{l}\text { THE EVOLUTIONARY FOUNDATIONS OF } \\
\text { ECONOMICS }\end{array}$ \\
\hline 15.10 & $\begin{array}{l}\text { Siddique, A., Selvanathan, E. A. and } \\
\text { Selvanathan, S. }\end{array}$ & $\begin{array}{l}\text { THE IMPACT OF EXTERNAL DEBT ON ECONOMIC } \\
\text { GROWTH: EMPIRICAL EVIDENCE FROM HIGHLY } \\
\text { INDEBTED POOR COUNTRIES }\end{array}$ \\
\hline 15.11 & Wu, Y. & $\begin{array}{l}\text { LOCAL GOVERNMENT DEBT AND ECONOMIC } \\
\text { GROWTH IN CHINA }\end{array}$ \\
\hline 15.12 & Tyers, R. and Bain, I. & $\begin{array}{l}\text { THE GLOBAL ECONOMIC IMPLICATIONS OF } \\
\text { FREER SKILLED MIGRATION }\end{array}$ \\
\hline 15.13 & Chen, A. and Groenewold, N. & $\begin{array}{l}\text { AN INCREASE IN THE RETIREMENT AGE IN } \\
\text { CHINA: THE REGIONAL ECONOMIC EFFECTS }\end{array}$ \\
\hline & & \\
\hline
\end{tabular}

